The Image of the Black Woman

in Gwendolyn Brooks' Poetry

Asst. Lecturer IKHLAS MUHAMMED NATI

University of Wasit - College of Education

\title{
Abstract:
}

Gwendolyn Brooks is a distinguished African-American poet of the twentieth century. She is a poet of a powerful voice with which she seeks to help generate a new view, and draw a new image, of her own as a black woman who is self-conscious of her race, gender and talent, and to help generalize this image. The present paper is an attempt to identify some general outlines of that image.

جويندلن بروكس شاعرة أمريكية من أصل أفريقي ذات صوت شعري يعد من الأصوات

الثعرية المتميزة في القرن العشرين، تسعى في شعرها إلى للتعبير عن رؤيا جديدة ورسم

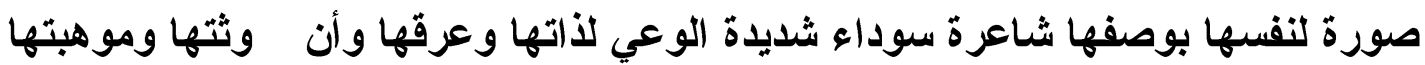

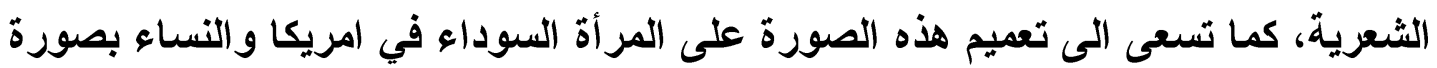

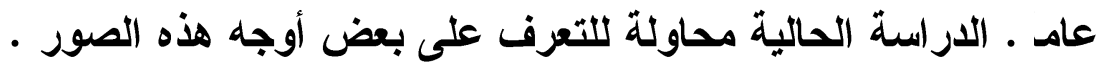

Gwendolyn Brooks was born in Kansas in 1917, during a time of havoc and disorder. It is the same year in which America went to war in Europe, and it is also the same year in which warfare erupted several times within the country's borders-between the white and black races. ${ }^{1}$ Her family moved to Chicago shortly after her birth, and being a "Chicagoan"" associated with the city's South Side, Brooks lived the atmosphere that accepts violence as a normal phenomenon in everyday life. This is very evident in her poems in which she reflects the daily life experience of the ordinary black people, a real image of simple woman who tries her best to survive in such difficult milieu. As a negro poet, Gwendolyn Books 
Was interested in writing poems that would reach the people she wrote about -the African American urban poor. Perhaps more than any other Poet, Brooks succeeded in capturing the hopes of this group,as well as their feelings of rage and despair in the face of racism and poverty. $^{3}$

Brooks' poetry emphasizes the reality of the life of black people, giving a close-to-the-bone picture of it. Keeny Jackson Williams says that she writes from "an intimate knowledge reinforiced by her own life." She wrote about everything in life especially the life of her race, the Afro-American people. She tries to reflect their suffering and their struggle against injustice caused by racial discrimination, and this is clearly shown in her poems. The following lines, to begin with, may be taken to be representative of the kind of verse she wrote. They are from a poem entitled "The Blackstone Ranger:"

There they are

Thirty at the corner

Black,raw,ready

Sores in the city

That do not want to heal. ${ }^{5}$

\section{(ll. 1-5)}

As Brooks herself described it, "The Blackstone Ranger" is "wild, raw and ragged free verse," verse. She says that they are "the black" minority in the State having no right to participate in the society. According to Louis Wirth, "minority status carries with it the exclusion from full participation in the life of the society." And most critics welcomed Brooks as a new voice in poetry, describing her as "a powerful voice of black consciousness and social protest." ${ }^{8}$ She transforms the facts and actualities of what she sees in the street into fine poetry which can be regarded as a real reflection of her age, this modern age, especially the experience and suffering of the Afro-American people. 
With her unique talent, she succeeded in manipulating reality and transforming it into art, showing considerable understanding of the magical relation between art and life and how life needs art, and vice versa, and understanding how the two overlap and are combined to produce a fine piece of poetry which reflects the real life in her environment. Brooks, in an interview in 1979, says:

I'm trying very seriously now to create for myself, develop for myself, a kind of poem that will be immediately accessible and interesting, immediately interesting to all manner of blacks, not just college students though they're included too. That kind of poem will feature song, will be songlike, and yet still properly called poetry. ${ }^{9}$

This is clearly shown in her short but very deep poem, "We Real Cool:"

We real cool.We

Left school.We

Lurk late.We

Strike straight.We

Sing $\sin . W e$

Thin gin .We

Jazz June .We

Die soon.

(ll. 1-8 )

It is an interesting, simple and song-like poem, but at the same time it very effectively reflects the reality of black people, their feeling of an uncertain, unstable and ambivalent reality. The poem depicts and the disordered lives of young black people who leave school into the street to lead the life of drop-outs, thus dramatizing -as in the last line-the tragic pathos of their lives. While Brooks seems to be concerned with the race she belongs to, her poetry at the same time 
talks about all kinds of people, regardless of their colour, age, and race. Her poetry is the core of such a difficult life. Brooks defined poetry as "the very sifting of life... Think of life as a rough powder that you pour through a sieve. "10 But one may wander what kind of powder Brooks spread throughout her world. Kenny Jackson says that her poetry is marked by "some unforgettable characters who are drawn from the underclass of the nation's black neighborhoods." 11 She has her special way to reflects and record the impact of city life in her poetry, as in her poem " Kitchenette Building :"

We are things of dry hours and the involuntary plan,

Grayed in, and gray. "Dream" makes a giddy sound, not strong

Like "rent," "feeding a wife," "satisfying a man."

Here, Brooks describes the hardship of daily life in a black environment where the inmates of the "kitchenette building" lead a poor and marginalized life. They are so trapped in this hard and harsh reality as to be turned into "things," as in the opening line of the poem. What makes this poem an effective expression of its theme is the contrast drawn between all these hardships of life which are so many on the one hand, and just one dream on the other. Brooks' poetry is thus "invigorated by her passionate portrayals of ordinary African American women and men and by her arguments against prejudice." 12

Brooks also addresses many other issues concerning the life of her gender. As Kathryn V.Lindberg writes,

Brooks has always addressed and continues to address difficult issues, including those often decorously silent intimate traumas of abortion, color cost, domestic abuse, alienation, and motherhood in poverty. Defiant in the face of a painful history of racist lies and false consciousness that refuse to yield a "useable past," she has actively fashioned models of personal and communal dignity as poetic blueprints for "cultural survival." 13 
Brooks presents a special image of the black woman who has had "a struggle for the emancipation of their race while contending with prejudice and policies in American life that discriminate against women." ${ }^{14}$ It was most difficult to be a black woman. For this Brooks is adept at writing from the point of view of a female, introducing the feminine psyche in which one can find a unified image of the womanthe mother, the wife and the girl- who lost her identity and who tries her best to gain her freedom. Brooks deals with such a vital matter concerning the life of any woman who tries her best to survive. Brooks "presents her characters with vitality and a sympathy that asks us to look beyond the superficial and to understand the world those characters live in."15 In her poem "The Mother," Brooks talks about sorrowful experience of a black mother who regrets having abortions. She surprisingly begins her poem with this word:

Abortions will not let you forget

You remember the children you got that you did not get,

In a world where abortion is considered either a woman's right or a sin against God, tension exists between the mother and this unjustified deed. Since this harsh experience could happen to any woman, Brooks chooses to say "you" rather than "I", to make the reader identify any woman and to make this sorrowful experience less a personal and universal one. The mother in this poem becomes a symbol of suffering and sterility instead of being a symbol of fertility and life. In this poem Brooks presents the female figure as a reflection of such a painful age; instead of giving her children life, the mother unwillingly takes it from them. Actually she felt deep sorrow when she remembered them. She expresses her longing and regret over the children she will never have, as in the following lines:

The damp small pulps with a little or with no hair,

The singers and workers that never handled the air, 
You will never neglect or beat

Them, or silence or buy with a sweet.

In these lines, Brooks tries to convey, to "the mother," a sense of longing for those little things, "her children," mothers are known to be good at.This is clear in the line, "You will never wind up the suckingthumb,or scuttle off ghosts that come." (Il. 7-8) Brooks keeps on telling the same feelings of sadness, remorse and longing. The mother in this poem stands for all female characters who experience this harsh feelings of loss. She loses the most precious thing in her life, a part of her ,"her children" and actually it is hard not to feel the sadness. Brooks expresses true emotions when in the last lines of the poem the woman attempts to reassure the children that she loved them with all her heart; she says:

Believe me, I loved you all.

Believe me, I knew you, though faintly, and I loved,

I loved

you

All.

Ending the poem by these lines proves that this mother is obliged to abort maybe because she is unable to take care of her babies, and it is the harsh times that pushed her to do this. The mother here becomes a symbol of sacrifice. She explains that this is not her fault or crime. Of course, it is something she cannot control .

If I poisoned the beginnings of your breaths,

Believe that even in my deliberateness I was not

Deliberate.

Though why should I whine, 
Whine that crime was other than mine?

(ll. 22-25)

Whose crime was it? Everybody knows that Brooks through this mother sends a message for all humanity, regardless of the gender, saying that "modern woman" lives a very difficult situation and she can hardly support herself to survive. For this reason, the female figure here stands as a reflection of all the miseries, pains and difficulties of modern life. Kathy Rugoff states that Brooks' works are "characterized by intense awareness of the African American experience, women's roles and feminist perspectives, and literary tradition." ${ }^{16}$

In "A Sunset of the City," Brooks presents a similar sorrowful feeling and longing of an old woman (another mother) for her children who have left her alone. She blames them because they left her suffering lonely, i.e. she badly needs someone to stay beside her, to take care of her, to treat her as a human, not like marbles and dolls. Actually she needs to feel the same feeling when she was young and needed by her husband and children. She feels life through them, the real essence of life to live with those whom you loved very much. But her children and her husband left her alone with her everlasting despair as if she were useless for them. They do not need her any more:

Already I am no longer looked at with lechery or love.

My daughters and sons have put me away with marbles And dolls,

Are gone from the house.

Again this old woman represents a mere reflection of sterility not fertility as usual. She is an old woman in her last days left alone 
waiting for her death. She shows an a painful awareness of this fact when she says:

It is a real chill out

The genuine thing,

I am not deceived, I do not think it is still summer

Because sun stays and birds continue to sing.

$$
\text { (ll. 6-9) }
$$

Then she successfully describes her situation in such a world:

I am a woman, and dusty, standing among new affairs

I am a woman who hurries through her prayers.

(Il. 19-20)

She gives a symbolic image of herself by describing herself as a dust standing among new affairs. No one needs her as if she has no place in this world and nothing to do except waiting for her death alone.

"Sadie and Maud" is another famous poem that reflects the times in which Brooks grew up. During the 1940's and 1950's, women across America were torn between choosing a simple domestic life and having a career. Here, and as usual, Brookes tries to reflect what happens around her, concentrating on the situation of women especially those of her race. "They have had to struggle for the emancipation of their race, while contending with prejudices and policies in American life that discriminate against women." 17

"Sadie and Maud" can therefore be considered a true reflection of such a struggle through which we can examine the life of two characters, each of whom has her special way to deal with the difficulties of her life. Each chooses her weapon to fight for her rights and freedom:

Maud went to college. 
Sadie stayed at home.

Sadie scraped life

With a fine-tooth comb.

(Il. 1-4)

Maud went to college and did everything that was asked of her; yet, she is the one who is, in the end, alone and afraid of life. Brooks tells us that Maud "who went to college, is a thin brown mouse." (Il. 17-18). She describes Maud as a thin, timid black woman all alone fearful of life." She is living all alone. In this old house." (1l.19-20). Perhaps, this is a clear call from Brooks to all black women who lost their chance to go to college and educate themselves, to wake up and improve themselves and search for their new identity as black women who, even if they were housewives and uneducated, still can gain their freedom and happiness. Sadie enjoys every moment of life and has two daughters to love and care for, and she dies young and happy. Sadie, on the other hand, takes the revolutionary way in her life through which she gains happiness.

In "The Crazy Woman," Brooks continues the revolutionary image of the modern woman. Although the poem's title emphasizes "craziness," yet, this craziness seems to be, according to Brooks and her revolutionary sense, is the right way to revolt against everything and to be yourself even if all the people call you crazy. It is a call to invent your proper way to live your life even if it were against tradition. The woman in this poem says,

I shall not sing a May song

A May song should be gay

I'll wait until November

And sing a song of gray.

(Il. 1- 4) 
Although the season in November is cold and freezing, this woman chooses to sing her song to celebrate her life at such time, not like the others who celebrate their life in summer. This woman is not like the others; she likes to be herself, a reason for which the others call her crazy, but she does not care. She cares only about her own life and how she would lead this life:

I'll wait until November

That is the time for me

I'll go out in the frosty dark

And sing most terribly

And all the little people

Will stare at me and say,

That is the crazy woman

Who would not sing in May

$$
\text { (11. 5-12) }
$$

The woman, here, stands for all the black people who should, according to Brooks, live their life and take their freedom and break the darkness of injustice.They should be brave and strong enough to stand against everything in this world. It is evident that the black are minorities in America, but they should, the poet seems to say, act like this woman, and stand against the whole community, against all types of racial injustice and gain their freedom. At the same time this woman represents a universal symbol of rebellion. She stands for all human beings who want to gain their freedom and their real identity especially those who lost their identity in such a hellish mess of the modern age. Blyden Jackson notes that "although Brooks wrote primarily about urban African Americans, her poems are brimming with insight and revelations of universal application." They speak to the human condition and hence to all the citizens of the world. ${ }^{18}$ 
A similar image of rebellion is found in Brooks' poem "Song in the Front Yard." It is about a woman who chooses her special lifestyle regardless of what others would say about her. She listens to no one but her inner heart which calls for freedom. To be free and different: this is what she really wants. She follows her desires and does not care even if the others think of her as a bad woman. When her mother advises her not to be like Jonnie Mae, "the bad woman," she says:

But I say it's fine. Honest, I do.

And I'd like to be a bad woman, too,

And wear the brave stockings of night-black lace

And strut down the street with point on my face.

This woman symbolizes the situation of all young woman who try their best to prove themselves and their identity in such a dilemma. They want to be united with any known person even if it is so bad only to prove their existence in such an age. One can regard this poem as a reflection of such a time in which the woman loses everything, including her identity. Thus, this image of the black woman "could apply to any female of a certain class and society." ${ }^{19}$ We see that Brooks tries to present in her poetry a universal symbol of the modern woman, regardless of color, race and gender. "What is your poet's premise?" Brooks was asked in a 1967 interview. Her answer was that it is to "'vivify the universal fact,' said Whitman. I like to vivify the universal fact, when it occurs to me. But the universal wears contemporary clothing very well." 20

To conclude, Gwendolyn Brooks maintained a high level of creativity by which she managed to reach the heart and the mind of her readers. In most of her poems which describe the ordinary life of female characters, she successfully manipulates these characters as representative of their society. To be free in this world, Brooks seems to be contending in many of her poems, is to be different, even if as 
different as a mad or an abnormal person. Her poetry is a plea, sometimes as loud as a cry, for the destruction of all chains, all restrictions and all discrimination, not only against the black, but also against all people who suffer in this world. Brooks' poetry forcibly expresses the hope that one day people will be equal, regardless of colour, race and gender.

\section{NOTES}

${ }^{1}$ Quoted in W. Augustus Low and Virgil A. Clift eds., Encyclopedia of Black Americans(New York: McGraw-Hill Inc., 1981), p.232.

${ }^{2}$ Quoted in Terence Allan Hoagowood, "On Gwendolyn Brooks: Reliant Contemplation" (http://www.questia.com/googleScholar.gst;jsessionid.2004) retrieved on $16^{\text {th }}$ May. 2010, p.2.

${ }^{3}$ Quoted in Beverly Ann Chin et al. eds., Glencoe Literature: The Reader's Choice(New York: McGraw-Hill Inc.,2003), p.842.

4 Ibid, p.3.

5 All reference to the poems of Gwendolyn Brooks are taken from the following source: Classic Poems: Gwendolyn Brooks(http://www.poemhunter.com(The World's Poetry Archive 2003). Retrieved on 4th, April, 2010.

6 Beverly Ann Chin et al eds Glencoe Literature: The Reader's Choice(New York: McGraw-Hill Inc.,2003), p.842.

${ }^{7}$ George Simpson and J. Milton Yinger,An analysis of prejudice and discrimination,Racial and Cultural Minorities, $3^{\text {rd }}$ ed.(NewYork:Harper\&raw Inc.,1953),p.16.

${ }^{8}$ Online Interviews with Gwendolyn Brooks

(http://www.english.illinois.edu/maps/poets/a-

f/brooks/interviews.htm,2005), retrieved on $10^{\text {th }}$, May,2010,p.3

9 Hoagwood ,p.4

10 Kenny Jackson Williams ,Brooks,life and career,(http://www.megaessays.com/view paper,2008),retrieved on 9th,May,2010,p.3

11 Dana Gioia and etal, ed. ,Twentieth -Century American Poetry,(NewYork:McGraw-Hill com.2004),p.543

${ }^{12}$ Ibid ,p.543

${ }^{13}$ Kenny Jackson Williams,p.3 
14 Harry A.Ploski and James Williams ed.,The Negro Almanac,A Reference Work on The Afro American(NewYork:Bellwether Publishing com.,Inc. 1983),p.1309

15 Quoted in Lisa Schnell and etal,WOMEN'S WORLDS,The MacGraw-Hill Anthology of Women's Writing(Bostsn:MacGraw-Hill com.Inc.,2008),p.1464

16 Quoted in Kathy Rugoff, The Historical and social context of Gwendolyn Brooks's poetry

(http://www.english.uiuc.edu/map/poets/a f/books/life.2005),retrieved on 4th,Jan,2010,p.4

17 Harry A.Ploski and James Williams,p.1309

${ }^{18}$ Beverly Annchin,p.842

${ }^{19}$ George eaton Simpson and J.Milton Yinger,p.475

${ }^{20}$ Gioia ,p.544

BIBLIOGRAPHY

Chin,Beverly Ann and etal.ed.Glencoe Literature,The Reader's Choice. New York: MacGraw-Hill Inc.,2003.

Gioia,Dana and etal.,ed.Twentieth-Century American Poetry. New York: MacGraw-Hill com.2004. Hoagowood, Terence Allan.On Gwendolyn Brooks:Relaint Contemplation

(http://www.questia.com/googleScholar.gst;jsessionid)retrieved on16th,May,2010.

Law,W.Augustus and Virgil A.Clift ed., Encyclopedia of Black American. New York: MacGraw-Hill,Inc.,1981.

Ploski,Harry A. and James Williams ed.The Negro Almanac,A Reference Work on The Afro-American .NewYork:Bellwether com.,Inc.1983.

Rugoff,Kathy.The Historical and social context of Gwendolyn Brooks's poetry (http://www.english.uiuc/edu/map/poets/af/books/life.2005)retrieved on4th, Jan, 2010.

Schnell,Lisa and etal.WOMEN'SWORLD, The MacGraw-Hill Anthology of Women's Writing.Boston:MacGraw Hill com.Inc.,2008. Simpson,George eatonand J.Milton Yinger .An analysis of prejudice and discrimina- Tion,Racial and Cultural Minorities.NewYork:Harper\&raw Incf.,1953.

Williams,Kenny Jackson.Brooks,life

and career(http://www.megaessays.com/view Paper,2008)retrieved on $9^{\text {th }}$,May,2010. 


\section{DAR. journal for Philosophy \& LINGUISTICS and SOCIAL SCIENCES NO. IV 2010}

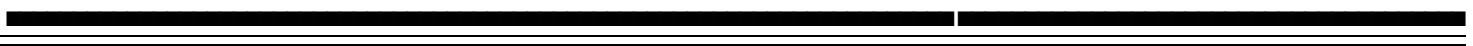

